\title{
Mental Illness: The Healing Power in Bessie Head's A Question of Power
}

\author{
Abdul Wahab \\ MA Student, Department of English, Lakehead University, Thunder Bay, Ontario, Canada.
}

\begin{abstract}
Bessie Head's A Question of Power is one of the great African literary pieces that deals with insanity. As a reader, I found it challenging to cope with the traumatic situations encountered by Elizabeth, the central character of this novel. She struggles with her two inner beings; Sello and Dan. Both of them represent either God or Satan or vice versa. To escape the violence of apartheid, Elizabeth leaves South Africa and immigrates to Motabeng, a village in Botswana. Elizabeth, like Bessie Head apparently leads her life alienated from the society. In South Africa, She experiences inhumanity, poverty, and mental torture as she has no truly pure identity. In apartheid period, intercourse between a white and a black person was illegal. Elizabeth's mother was white and her father was black and she is neither white nor black. In Botswana, she was an outcast in the society again because she was unfamiliar with language and culture of Botswana. So, Elizabeth's isolation from the entire world, her poverty and the extreme violence of Sello and Dan eventually force her to suffer mental illness. Though on a superficial level, it seems that Elizabeth's insanity gives her nothing except mental and physical trauma; her illness brings freedom and peace for her at the end of the novel. So this paper will analyze the impact of the state of insanity to prove that Elizabeth's mental illness strengthens her power to understand social and political issues which ultimately leads to the reconciliation of her body and soul in A Question of Power by Bessie Head.
\end{abstract}

Keywords-A Question of Power, Apartheid, Bessie Head, Mental Illness, Reconciliation, South Africa,

Bessie Head's A Question of Power is an African literary narrative that considers the theme of mental illness via the female protagonist, Elizabeth. For readers, it is often challenging to cope with the traumatic situations Elizabeth encounters because she herself battles to cope with her inner anxieties. These inner anxieties exist within Elizabeth because of the two internal figures, Sello and Dan, who represent God and Satan and further affect her mental illness. The source of her mental illness comes from a prophecy early in her life when a school missionary warns her saying, "Your mother was insane. If you are not careful you'll get insane just like your mother.
Your mother was a white woman. They had to lock her up, as she was having a child by the stable boy who was a native" (Head, 16). This prophecy impacts on young Elizabeth's mind heavily. She subconsciously bears these words of prophecy in her whole life what causes her mental trauma. Elizabeth's mother was white and her father was black and she is neither white nor black. Moreover, in South Africa, Elizabeth experiences inhumanity, poverty, and mental torture during apartheid because her true identity is unstable. So, to escape the violence of apartheid, Elizabeth leaves South Africa and immigrates to a village in Botswana. But as a refuge in new place, she turns into an outcast in the society again because she was unfamiliar with language and culture of Botswana. Like Bessie Head, Elizabeth appears to lead a life of alienation outside of the rest of society. As such, because of some inevitable reasons for instance; the isolation from the entire world, her mother's historical background in her mind, her poverty and the extreme violence from Sello and Dan eventually force her to confront her struggle with mental illness. I argue that Elizabeth's mental illness strengthens her power and association with social and political issues, which ultimately lead to the reconciliation of her body and soul. Although Elizabeth's insanity appears to give her mental and physical trauma, a deeper understanding of her illness shows that she can gain freedom and peace in her life.

I will begin by discussing Elizabeth's isolation and how this affects her mental state. Even though Elizabeth is isolated from society, she is able to embrace her loneliness because she has the ability to avoid the torture and turmoil that come from larger social issues such as; conflict with the native people, hierarchy and social class, patriarchy and other forces of power against females in society. Throughout her life of alienation and inner battles with mental illness, Elizabeth is able to move forward and cope with her struggles: "I like the general atmosphere because I don't care whether people like me or not. I am used to isolation" (Head 56). Elizabeth's movement into this state of isolation helps her cope with and understand how to live alone while she is an exile in Botswana. Through isolation and loneliness, Elizabeth creates her own world where she lives with three inner 
figures: Sello, Dan, and Medusa. Relatedly, Elizabeth's madness helps her to create these three characters whom she often encounters and engages with.

Although most of her conversions display her anxiety, mental torture, and inner struggle, Elizabeth learns many of the things she understands about life from her conversations with Sello and Dan. She depicts and sees Sello as her friend and someone who gives shape to her philosophical world and understanding of the spiritual meaning of love, life, and God. As the days progress, Elizabeth appears to become more dependant on Sello: "[S]he was entirely dependent on Sello for direction and equally helpless, like a patient on his doctor for survival" (35). Here, Head suggests that even though Elizabeth's hallucinations makes her victim to loneliness, her hallucinations of seeing Sello allows her to have company and share her struggles with someone who gives her medical advice. Throughout the development of their friendship, Elizabeth travels with Sello into the history of mankind and race where he teaches her about the "lovers of mankind" (202). Considering this idea of learning about race and mankind, Head writes, "They have roamed together as barefoot monks. [...] no lovers had caressed them in their solitary meditations on the soul, yet they had been lovers of mankind" (202). Throughout Elizabeth's spiritual journey, not only does she view the history of mankind, but she also considers a solution to the problem of cruel and harsh attitude. She thinks that the harsh attitude of humans is the reason that others suffer, therefore, Elizabeth aims to teach softness and compassion to mankind: "[T]he work she and Sello had done together had introduced a softness and tenderness into mankind's history" (202).Through this lesson of kindness, Elizabeth learns that both communication and sharing are important for humans to be able to interact with others within society.

In her reality, Elizabeth is not able to share her feelings and thoughts with anyone during her early time in Botswana. She is, however, able to share some of her thoughts with Sello. When Head states, "They had perfected together the ideal of sharing everything and then perfectly shared everything with all mankind" (202), this suggests that Elizabeth's ideal of sharing can bring peace to her mind. Therefore, her ability to share her spiritual journey, thoughts and struggles with Sello play an important role that helps to lead Elizabeth away from a life of madness and illness. Elizabeth cherishes her friendship with Sello even though this friendship exists in another world: "'Sello,' she said, 'if you say our friendship will never end, that means we are supposed to meet again in other lives" (201)? This statement from Elizabeth shows readers how desperate she is to gain companionship. Sello represents a part of Elizabeth who is eventually able to reduce her loneliness and help her cope with her anxieties from her mental illness. On one hand, Sello is a figure that symbolizes Elizabeth's ability to work toward overcoming her illness; therefore, Sello can also be viewed in relation to Rama, Krishna or Buddha. On the other hand, Elizabeth learns the opposite lessons of life from Dan through mental anguish and trauma.

Unlike Sello, Dan is much more destructive in nature. He is a sexually perverted person who tortures Elizabeth in various ways. He represents the power of patriarchy and male domination over the female figure in South African society. Elizabeth experiences oppression composed by the male power through Dan's activities and learns to survive under pressure. She learns how to encounter male power as a victim. Dan prompts her to commit suicide as he says again and again "You're going to commit suicide" (186) but Elizabeth does not allow herself to be killed. She also argues against Dan when he says, "Die, die, die, you dog! I hate you! I hate you!" (173), and then Elizabeth continues to argue saying, "why, why, why? What have I done" (173)? This encounter with Dan exposes the inner quality and power of Elizabeth. Although Dan's approach is mostly that of an enemy, Elizabeth depicts him as a teacher too as she says, "Under other circumstances, Dan would have been the perfectionist, the great teacher. He raked the personality over with the eyes of a hawk and grasped hold of all the weak spots. The great teachers had done the same" (136). This discloses that although Dan plays the role of a villainous character, Elizabeth gains strength and the ability to cope because of his appalling behavior. After leaving her country for Botswana, Elizabeth copes with her illness because she spends her time hallucinating visions of Dan and Sello. Although she is separated from the rest of society, she is able to communicate with Sello and Dan within her new reality that she creates for herself.

Sometimes, it is not easy to fight back against the evil forces within a society and individuals have to disguise their voices against established, higher powers and authorities. In A Question of Power, Head uses madness or insanity as one kind of dynamic force to fight back against apartheid violence, patriarchy, and racial political views because sometimes it is the only possible way to raise voice against these powerful authorities. Therefore, in the text, insanity is a metaphor that connects the ideas of madness and spirituality together to represent Elizabeth's struggles.

Elizabeth discovers problems within her society and because of her own experience with struggles; she suggests possible worldly and spiritual solutions for the problems she encounters. By observing Dan's character 
closely, the reader can see that Elizabeth attempts to analyze the social defects of South Africa:

"The social defects of Africa are, first the African man's loose, carefree sexuality; [...] The second defect is a form of cruelty, really spite, that seems to have its origin in witchcraft practices. He (Dan) was super-combination of both these defects, [...] To sex, he added homosexuality and perversions of all kinds. To witchcraft terror, he added the super staying power of his elemental soul" (137). The history of apartheid is all about cruelty where white people oppress black people physically and mentally. Some black people choose exile in another country like Elizabeth; some go insane or die during apartheid. Like Elizabeth's husband, South African people's sexual life is careless. Her husband goes for every woman he likes. Elizabeth thinks South African people do not respect their sexual life; there is no bondage or mutual understanding between partners. Most of the women are only considered as sexual object rather than human beings.

In her madness, Elizabeth does not only search for problems of South African society, she also finds out possible solutions for people. She explores the meaning of God, heaven and the human soul to demonstrate how human society can achieve eternal peace. First, she challenges the traditional idea and definition of God by asking, "[W]hy an absolute title has been shared. There are several hundred thousand people who are God" (31). In this statement, Elizabeth indicates those people are gods who hold power in the society. For example, white people, and people who operate state or government, police, army or other authorities hold this power within society. Elizabeth then searches for a true God who can be closer to a human being and establishes the definition of her God. In Elizabeth's definition, "God is the totality of all great souls and their achievements; the achievements are not that of one single, individual soul, but of many souls who all worked to make up the soul of God, and this might be called God, or the Gods" (54). So, only when all great human souls and their achievements tie together, the existence of God then get established. Now, if there is God, there is a heaven too. As Elizabeth views human souls as her God, her heaven belongs to human beings too:

"a heaven had been planned directly around the hearts of men and as, bit by bit, its plan unfolded they call it so many names: democracy, freedom of thought, social consciousness, protest, human rights, exploration, moral orders, principles, and thousands and one additions for the continual expansion, and evolution of the human soul" (54). Through her mental illness, Elizabeth expresses here the functions of human souls in life. She depicts various human activities as heaven when those acted by the human hearts. Her philosophical view towards God and heaven is unique and the result of her insane mind, which suggests the ultimate way to achieve peace for mankind. To her, mankind can achieve peace when all good souls can get together.

Head shows her readers that madness and mental illness are not seen as states of weakness for Elizabeth, rather, they act as types of resistance enabling Elizabeth to think and sort out problems of human life. She also possesses the ability to solve these problems. For Head,"[t]he victim is really the most flexible, the most free person on earth. He doesn't have to think up endless laws and endless falsehoods. His jailer does that. His jailer creates the chains and the oppression. He is merely presented with it. $\mathrm{He}$ is presented with a thousand and one hells to live through, and he usually lives through them all" (84). As a victim of madness, Elizabeth is free and flexible to think about society and her madness makes her able to criticize any established authority whether it is the authority of human or God.

Elizabeth is separated from human society due to her biracial identity and cultural differences from the local Botswana people. After having her first mental breakdown, she is asked to submit a certificate of sanity by the schoolprincipal but Elizabeth refuses and leaves her teaching job. This is the first physical revolutionary reaction she displays during her insanity. Leaving her job, she starts gardening and marketing garden products in the village with good members of the community. The gardening project brings Elizabeth close to community and social connection. Here she gets a group of people to mix with who help her to reshape her communication ability and develop her sense of the real world. Elizabeth makes friends with Kenosi, Mrs. Stanley, Mrs. Jones, Tom and others in the garden project. Her ability to form friendships with people gives her confidence to become a more active social being and activist. For the first time in her life, she works, shares and laughs with people. Kenosi is her good co-worker who always follows her word, who loves her and appreciates her work in the garden. Mrs. Jones, Mrs. Stanley, and Tom are the regular visitors at Elizabeth's house.

Tom is a white American who is a very passionate listener for Elizabeth. The relationship between Tom and her is interesting and thought provoking because Elizabeth hates white people since "most of the Gods are born among them" (29). Since she witnessed that the white people colonized in South Africa and oppressed the black community, she considers the white as god-power. So, she hates the white people. Now, her relationship with Tom indicates that she achieves the ability to adapt to the social and political changes that occur in the society. She shares her illness, philosophical thoughts and 
views of life with Tom so often that it reduces her sense of fear of being disoriented. So, she wants more care from Tom to protect her from evil forces as she utters, "Tom, you like to take care of people. Will you take care of me the way you care for others" (136)? This indicates the good connection made between Elizabeth and Tom. Apart from Tom, her connection with Mrs. Jones and Mrs. Stanley is remarkable. She views Mrs. Jones as a mother figure. Though Mrs. Jones does not speak that much, she likes her because of her motherly affection. Like everybody in garden project, Mrs. Jones bears important characteristics too who symbolically reminds her about the life of so simple and humble women of South Africa as in Head's words: "The attractive thing about her, though, was that she was a replica of the humanity of the slum women Elizabeth had to grown up with in South Africa" (170). Mrs. Stanley also becomes a good friend of Elizabeth. Mrs. Stanley takes responsibility for Elizabeth's son. She takes the boy for holi day breaks so that Elizabeth can feel safe and secure about her only child. So, all the relationships Elizabeth builds up in the garden project for example, with Kenosi, Tom, Mrs. Jones and Mrs. Stanley demonstrates her ability to mix with people that was latent before starting gardening.

The gardening not only ensures a community life for Elizabeth but also it flourishes her ability of productivity. She was unaware and confused about her ability to produce anything. Dan threatens her saying, "Look, I'm going to show you how I sleep with B... She has a womb I can't forget. When I go with a woman, I go for one hour. You can't do that. You haven't got a vagina" (13). Here, female organ symbolizes productivity. As Elizabeth has "not got a vagina", she is an unproductive woman but in gardening project Elizabeth attains her power of productivity. She produces a gigantic cabbage, Cape gooseberries, spinach and many vegetables in the garden. The production of Cape gooseberries has special importance for Elizabeth. As Head remarks:

"...the village women always passed by Elizabeth's house to collect firewood in the bush. If they saw her in the yard, they stopped, laughed and said: 'Cape Gooseberry'... they did it so often that eventually Elizabeth became known as 'Cape Gooseberry'. A complete stranger like the Cape Gooseberry settled down and became a part of the village life of Motabeng" (153). Thus, Cape gooseberry symbolizes Elizabeth's settlement in Motabeng village because it was unknown to the village people and the land was believed to be nonproductive. Even, the village women start calling her Cape gooseberry as she produces it in plenty. Elizabeth says, "The ladies of the village came down to the garden with baskets on their arms. They always wanted spinach and cabbage" (157). This statement proves that
Elizabeth's productivity is acknowledged by the village dwellers in Botswana. Later on, this acknowledgment goes beyond Motabeng village when Head writes, "To Elizabeth's surprise, the English volunteers were just as mad about vegetables as were the village ladies" (203).Therefore, both the Motabeng village people, and foreigners from England appreciate Elizabeth's work in the garden what indicates that she regains her power of productivity what is negated by Dan earlier.

Apart from the gardening project, Elizabeth's sense of motherhood is another strong example of her productivity. Unlike her own mother, Elizabeth mothers her son successfully. Her mother goes insane and commits suicide. Elizabeth goes insane but she does not allow herself to commit suicide even though she lives with suicidal impulses. She always cares about her son. Once, in her hallucination, Dan predicts that her son would die within next two days from fever and she takes her child to the hospital right away. This anxiety and concerns explain enough about her motherhood. Again, we can observe her motherly affections towards Tom too. When Elizabeth is taken to hospital after having her mental breakdown, Tom visits her. A hospital nurse asked Elizabeth "perhaps he's your boy-friend" (183)? In reply, Elizabeth says out laughing "I'm as old as his mother. He's my son" (183). So, her sense of motherhood is as strong as the mental power to cope with her mental illness, which overpowers her insanity in A Question of Power.

Once Sello teaches Elizabeth that "love isn't like that. Love is two people mutually feeding each other, not one living on the soul of the other like a ghoul" (13-14). Elizabeth finally understands her sufferings and realizes that true love is essential for mankind to overcome all sufferings; the kind of love which includes all human beings and establishes equality among all: "[t]hat was the essential nature of their love for each other. It had included all mankind, and so many things could be said about it, but the most important that it equalized all things and all men" (202). Elizabeth discovers the reasons for human sufferings too. In her words, "Since man was not holy to man, he could be tortured for his complexion, he could be misused, degraded and killed" (206). So, according to her, when human being is unholy or not trustworthy each other, they suffer from worldly miseries and only pure soul's love can reduce those miseries what she calls "brotherhood" (206).

There are many revelations and lessons Elizabeth learns through her mental anguish, but most important thing Elizabeth learns is to value herself as a human being. Her statement "There is only one God and his name is Man. And Elizabeth is his prophet" (206) demonstrates that she values her existence in this world. This revelation clearly 
reverses Elizabeth's position as she switches herself from the position of victim of insanity to the position of a sane and wise human being. This realization of her life comes through a long journey into her mental illness. Elizabeth was confused about her true identity throughout this novel because she is neither white nor black by race and she is neither South African nor Botswanian by national identity. But her revelation and realization in the end of the novel suggest that she has achieved her true joyous and peaceful life as in Head's words, "A peaceful, meditative privacy settled on her mind. Her painful, broken nerve-ends quietly knit together. She put Shorty to bed and, for the first time in three years, embraced the solitude of the night with joy" (206). Elizabeth's mental peace proves that she has transformed herself from a state of not belonging to the sense of belonging. So, Head's phrase "gesture of belonging" indicates the reconciliation of Elizabeth's body and soul.

Because a Question of Power is a fictional autobiography, Bessie Head also experiences mental illness like Elizabeth, the central character. By writing her own experiences as a fictional work, Head refuses to be an object of patriarchal power. Insanity is not a weakness for Head rather it is one kind of strength because madness or insanity is sometimes viewed as a blessing as Elinettie Kwanjana Chabwera writes in her essay: "In ancient Greece, madness was seen as both a blessing and a curse. As a curse, it was expressed in epilepsy, mania, melancholia or paranoia, while as a blessing it was believed to bring gifts such as prophecy and poetry" (64). Based on the discussion of this paper we can assume that in the case of Head, madness works like a blessing as it helps her to write this novel.

Moreover, writing itself is a kind of resistance what Cixous calls as a movement for women. She writes in her essay, "The Laugh of the Medusa, "Woman must put herself into the text - as into the world and into history by her own movement" (3). A Question of power is real kind of movement for women what Head writes against patriarchal power, white power, politics of apartheid and so other evil forces in the contemporary society. Cixous also says, "Write your self. Your body must be heard. Only then will the immense resources of the unconscious spring forth" (8). Head's writing certainly spreads her physical and psychological pain and struggle into every woman's heart in the world. Every reader feels pain when reading and experiencing Elizabeth's mental trauma, but the readers also feel proud simultaneously when they discover Head's mental power to write her pain and overcoming her mental illness and insanity. Although A Question of Power is a work of fiction, it is partly Bessie Head's autobiography that encourages all women to cope while living under any humiliation. Women can learn from this novel how to achieve physical and psychological reconciliation experiencing any sort of traumatic situation in life. The reader can discover how the mental illness or insanity can be used as a healing power to reduce mental agony. Moreover, sometimes it can be an instrumental to elevate someone's intellectual pursuit that Bessie Head has done successfully through writing this novel.

\section{REFERENCES}

[1] Cixous, Hélène. "The Laugh of the Medusa." The Norton Anthology of Theory and Criticism ed. Vincent B. Leitch. New York: W.W. Norton \& Company, Inc., 2001, pp. 1938-1959.

[2] Chabwera, ElinettieKwanjana. "Madness and Spirituality in Bessie Head's A Question of Power." African Studies Bulletin 71, 2009-2010, pp. 59-70.

[3] Head, Bessie. A Question of Power. London, England: Heinemann, 1974.

[4] MacKenzie, Craig. "A Question of Madness: ReReading Bessie Head's A Question of Power." Current Writing: Text and Reception in Southern Africa vol. 26, no. 2, 2014, pp.148- 156.

[5] Pearse, Adetokunbo. "Apartheid and madness: Bessie Head's- A question of power." Kunapipivol. 5, no. 2, 1983, pp.80-93. 